\title{
Analysis of the Genetic Effects to Frogs (Fejervarya limnocharis) After Acute Lead Exposure In Vivo
}

\author{
B. Tengjaroenkul*, S. Boonmee** and L. Neeratanaphan**† \\ *Research Group on Toxic Substances in Livestock and Aquatic Animals, Khon Kaen University, Khon Kaen 40002, \\ Thailand \\ **Department of Environmental Science, Faculty of Science, Khon Kaen University, Khon Kaen 40002, Thailand \\ $\dagger$ Corresponding author: L. Neeratanaphan; hlamya@kku.ac.th
}

\section{Nat. Env. \& Poll. Tech. Website: www.neptjournal.com \\ Received: $14-01-2020$ \\ Revised: $24-02-2020$ \\ Accepted: $16-04-2020$ \\ Key Words: \\ Genotoxicity \\ Genetic differentiation \\ Lead; Frog \\ Fejervarya limnocharis}

\begin{abstract}
This study aimed to investigate the bioaccumulation and elimination of lead $(\mathrm{Pb})$ in Fejervarya limnocharis frogs as well as to determine the genotoxic effects of direct $\mathrm{Pb}$ exposure at different concentrations and lengths of time. Four varying concentrations $\left(0,5,10\right.$ and $\left.20 \mathrm{mg} \cdot \mathrm{L}^{-1}\right)$ of lead acetate $\left(\mathrm{Pb}\left(\mathrm{CH}_{3} \mathrm{COO}\right)_{2}\right)$ solutions were injected intraperitoneally into $F$. limnocharis. The concentration of $\mathrm{Pb}$ in the water samples used to house the frogs and the concentration of lead in frog muscle tissues were analysed at 24,48 and 72 hours after injection by inductively coupled plasma optical emission spectrometry. $\mathrm{Pb}$ was detected at a level that exceeded the standard $\left(0.03 \mathrm{mg} \cdot \mathrm{kg}^{-1}\right)$ in all samples of frogs injected with $\mathrm{Pb}$. The water samples indicated that the $\mathrm{Pb}$ concentrations were significantly different from the control $(p<0.05)$, except for the 5 and $10 \mathrm{mg}^{-\mathrm{L}^{-1}}$ concentrations after 24 hours groups and $5 \mathrm{mg} \cdot \mathrm{L}^{-1}$ concentration after 48 hours group. Only the concentration of the water in the 20 $\mathrm{mg} \cdot \mathrm{L}^{-1}$ for 72 hours group exceeded the standard $\left(0.05 \mathrm{mg}^{\mathrm{L}} \mathrm{L}^{-1}\right)$. Genetic differentiation was studied by inter simple sequence repeats (ISSR) with dendrogram construction and analysis of genetic similarity (S) for each duration of exposure. A total of 1158, 1205 and 1277 bands were generated by ISSR for the 24, 48 and 72 hours groups, respectively. In each dendrogram, individual injections with the same $\mathrm{Pb}$ concentration clustered together, and it appeared that higher concentrations resulted in greater genotoxicity. Genotoxicity was concentration- and time-dependent, with a correlation between the concentration and S-value for the 72 hours group $\left(R^{2}=0.77, p<0.05\right)$. In addition, this study could provide a basic application to develop $F$. limnocharis as a biomarker for $\mathrm{Pb}$ contamination by measuring genotoxic consequences.
\end{abstract}

\section{INTRODUCTION}

Lead $(\mathrm{Pb})$ contamination is an important environmental problem that affects water, soil and air quality worldwide (Mitchell et al. 2011, Jaishankar \& Mathew 2014). Pb contamination is especially problematic near mines, at sites of industrial wastewater discharge and from leachate from polluted areas. $\mathrm{Pb}$ is detrimental to various animals, and its toxicity can harm human health as the accumulation of $\mathrm{Pb}$ reaches excessive levels (IARC 2004, Martin \& Griswold 2009, Olafisoye et al. 2013). Pb can enter creatures through many routes, including skin contact, consumption of contaminated foods and water and breathing contaminated air (Kakker \& Jaffery 2004, Yan et al. 2018). Low-level $\mathrm{Pb}$ toxicity is often nonspecific and may cause fatigue and intellectual impairment (Méndez-Gómez et al. 2008). Severe $\mathrm{Pb}$ toxicity affects multiple organ systems and can result in renal, haematological, neurological and cardiovascular diseases (Correia et al. 2000, Kalia \& Flora 2005, Navas et al. 2007, ATSDR 2007). Pb toxicity can occur in kidney, spleen, heart, liver, lung, bone, brain and skeletal muscle (Patra et al. 2001, Vargas et al. 2003, ATSDR 2007, Sharma et al. 2011). Acute and chronic $\mathrm{Pb}$ toxicity in organisms depends on the concentration and duration of exposure (Needleman 2004, ATSDR 2007, Cleveland et al. 2008).

Furthermore, several published reports have revealed that $\mathrm{Pb}$ causes genotoxicity and cytotoxicity through oxidative stress and DNA damage (Kasuba et al. 2004, Zhang \& Li 2013). The genotoxicity of $\mathrm{Pb}$ is related to the oxidative stress that occurs when there is a lack of proportion between the formation and removal of reactive oxygen species (ROS). During oxidative stress, ROS impair cells by oxidizing membrane lipids and proteins as well as DNA. DNA damage is a process with a facilitative role for $\mathrm{Pb}$ in carcinogenesis and cell death (Kosnett 2006, Beyersmann \& Hartwig 2008). 
Polymerase chain reaction with inter simple sequence repeats (PCR-ISSR) is a technique that can be used to analyze genetic relationships using molecular markers and has high resolving power at the population level without prior molecular knowledge of the organism (Zietkiewicz et al. 1994, Wu et al. 1994). This technique can be used to detect various types of genetic differentiation or DNA damage and mutations, such as point mutations, rearrangements and small deletions or insertions of DNA in plants and animals (Neeratanaphan et al. 2014, Mahfouz \& Rayan 2016, Al-Qurainy et al. 2017). The ISSR method represents one of the most promising tools for the detection of genetic alterations in response to heavy metal toxicity by looking directly at the DNA sequence and structure (Behura 2006, Héry et al. 2008).

Amphibians are sensitive and important indicators to exposure to environmental pollutants because of their extremely permeable skin (Huang et al. 2007, Falfushinska et al. 2008, Kerby et al. 2010, Burlibasa et al. 2011). The rice field frog (Fejervarya limnocharis) is a native species found in Southeast Asia, including Thailand, Laos and Cambodia (Liu et al. 2011), and this creature is an important animal in the food chain, particularly on agricultural land in Southeast Asia. The toxicity of $\mathrm{Pb}$ has been studied widely in fish, but evidence relating to amphibians is relatively sparse (Linder \& Grillitsch 2000). Some studies have related the concentration of $\mathrm{Pb}$ in amphibians to that in their surrounding environment; however, these field studies cannot establish causes and effects. Therefore, laboratory-based studies are required to reveal the effects of $\mathrm{Pb}$ accumulation in $F$. limnocharis by simulation of environmental exposure. A frog (F. limnocharis) model was chosen for this study because this frog species is abundant in aquatic ecosystems. The objectives of the study were to investigate the concentrations of $\mathrm{Pb}$ in $F$. limnocharis and water after in vivo injection with different concentrations of lead acetate for different exposure times and to determine the relationship to genomic changes using the PCR-ISSR technique.

\section{MATERIALS AND METHODS}

Experimental design: Frogs of the species Fejervarya limnocharis, weighing approximately 15 grams, were collected from a private culture farm located in Khon Kaen Province, Thailand. Healthy F. limnocharis were randomly selected for the experiment. The frogs were allowed to acclimate to the laboratory conditions for 5 days and then randomly divided into 12 experimental groups: 3 control groups and 9 treatment groups. The experiments were performed in triplicate with 5 frogs in each group. Each plastic bucket as the experimental unit had a $15 \mathrm{~L}$ capacity and contained 1 $\mathrm{L}$ of dechlorinated tap water.
Lead acetate exposure concentration: For the lead acetate exposure study, $100 \mu \mathrm{L}$ of deionized water (control groups 1-3) or solutions of $\mathrm{Pb}\left(\mathrm{CH}_{3} \mathrm{COO}\right)_{2}$ (experimental groups 4-12) of varying concentrations (5, 10 and $20 \mathrm{mg} . \mathrm{L}^{-1}$ ) were prepared and applied to the frogs. At each concentration, the frogs were exposed to the injected solution for 24,48 or 72 hours before being analysed. The water in the buckets was not changed during the experimental period.

Lead acetate analysis in frogs ( $F$. limnocharis): Frogs of the species $F$. limnocharis were anaesthetized with ice, and the muscle samples were cut into small pieces. Exactly $1 \mathrm{~g}$ of muscle tissue was placed into a beaker and digested with $7 \mathrm{~mL}$ of concentrated nitric acid $\left(\mathrm{HNO}_{3}\right)$ and $1 \mathrm{~mL}$ of concentrated hydrogen peroxide $\left(\mathrm{H}_{2} \mathrm{O}_{2}\right)$, placed in a water bath at $90 \pm 5^{\circ} \mathrm{C}$ for 2 hours, and then allowed to cool to room temperature. The digested muscle samples were adjusted to a final volume of $25 \mathrm{~mL}$ with deionized water and then filtered.

Inductively coupled plasma optical emission spectrometry (ICP-OES) analysis: The digested samples of water and frog muscle were analysed for their $\mathrm{Pb}$ concentrations using ICP-OES. The ICP-OES wavelength for $\mathrm{Pb}$ analysis was set at $220.353 \mathrm{~nm}$. The detection limit of $\mathrm{Pb}$ was $0.005 \mathrm{mg} . \mathrm{L}^{-1}$. The precision of the metal concentrations was evaluated with a certified reference material (CRM) via the $3111 \mathrm{C}$ method (APHA 2005, Chand \& Prasad 2013).

Genotoxicity analysis: Total genomic DNA was extracted from F. limnocharis livers using a Genomic DNA Extraction Kit (Tissue) (RBC Bioscience) following the kit protocol. Extracted DNA was inspected by $0.8 \%$ agarose gel electrophoresis and ViSafe Green gel staining.

Later, a polymerase chain reaction was performed with a reaction mixture $(10 \mu \mathrm{L})$ consisting of BlueMix DNA polymerase MasterMix (RBC Bioscience), $1.25 \mu \mathrm{M}$ primers and $20 \mathrm{ng}$ of genomic DNA extracted from $F$. limnocharis liver tissue. Twenty-four ISSR primers were screened with DNA from the representative frogs at the different concentrations and at each duration length, and the experimental primers were selected based on their amplification profile. The 14 primers that amplified favourably for the 24, 48 and 72 hours experiments are shown in Table 1.

The PCR profile was demonstrated by predenaturation at $94^{\circ} \mathrm{C}$ for 5 minutes, 35 cycles of denaturation at $94^{\circ} \mathrm{C}$ for 1 minute, annealing at $52^{\circ} \mathrm{C}$ for 1 minute and 30 seconds, and extension at $72^{\circ} \mathrm{C}$ for 2 minutes, and a final extension at $72^{\circ} \mathrm{C}$ for 7 minutes using a thermal cycler (Analytik Jena). After amplification, the PCR products were resolved by electrophoresis on 2\% agarose gels and ViSafe Green gel staining.

Data analyses: The $\mathrm{Pb}$ concentrations in the water and frog samples were analysed using ANOVA followed by Tukey's 
Table 1: List of ISSR primers according to the duration of exposure.

\begin{tabular}{|ll|}
\hline 14 ISSR primers amplified & \\
\hline 5'-CTCTCTCTCTCTCTCTGC-3' & 5'-GAGGAGGAGGC-3' \\
5'-CACACACACACAAC-3' & 5'-CTCCTCCTCGC-3' \\
5'-CACACACACACAGT-3' & 5'-GTGGTGGTGGC-3' \\
5'-CACACACACACAAG-3' & 5'-ACTGACTGACTGACTG-3' \\
5'-CACACACACACAGG-3' & 5'-GACAGACAGACAGACA-3' \\
5'-GAGAGAGAGAGACC-3' & 5'-ACACACACACACACACG-3' \\
5'-CACCACCACGC-3' & 5'-CCCTCCCTCCCTCCCT-3' \\
\hline
\end{tabular}

post hoc test. The results are expressed as the mean \pm SD. All statistical data were carried out with SPSS for Windows (version 19), and the significance level was set at $\mathrm{p}<0.05$.

Polymorphic bands amplified by the ISSR markers were scored as present $=1$ or absent $=0$ compared to a standard DNA ladder. The data were entered into NTSYS-pc version 2.10p (Rohlf 2009) to construct the dendrogram and perform statistical analysis. Regression analysis was performed using SPSS.

\section{RESULTS AND DISCUSSION}

$\mathrm{Pb}$ concentrations in the water and $\boldsymbol{F}$. limnocharis samples: The $\mathrm{Pb}$ concentrations in the water after $F$. limnocharis were injected with $\mathrm{Pb}$ concentrations of 0 , 5, 10 and $20 \mathrm{mg} . \mathrm{L}^{-1}$ for exposure times of 24,48 and 72 hours are given in Table 2 . The $\mathrm{Pb}$ concentrations of the water samples did not exceed the standard of the Pollution Control Department of Thailand of water quality standards (0.05 mg.L $\mathrm{L}^{-1}$ ) (TPCD 1986), except for the highest $\mathrm{Pb}$ concentration of the $20 \mathrm{mg} . \mathrm{L}^{-1}$ for 72 hours $(0.05 \pm 0.01$ $\left.\mathrm{mg} . \mathrm{L}^{-1}\right)$. The $\mathrm{Pb}$ concentrations of the water samples between the experimental and control groups were significantly different $(p<0.05)$ for all experimental groups except for the 5 and $10 \mathrm{mg} . \mathrm{L}^{-1}$ groups for 24 hours and $5 \mathrm{mg} . \mathrm{L}^{-1}$ group for 48 hours.

The $\mathrm{Pb}$ concentrations in $F$. limnocharis muscle after injection with different $\mathrm{Pb}$ concentrations and durations of exposure are given in Table $3 . \mathrm{Pb}$ was not detected in the $F$. limnocharis muscles of the control group. The $\mathrm{Pb}$ concentrations of $F$. limnocharis muscles in all experimental groups exceeded the standard of the Pollution Control Department of Thailand (0.03 mg. $\mathrm{kg}^{-1}$ ) (TPCD 2001). The highest $\mathrm{Pb}$ concentration was found in the 20 $\mathrm{mg} . \mathrm{L}^{-1} 72$ hours group $\left(0.78 \pm 0.04 \mathrm{mg} \cdot \mathrm{kg}^{-1}\right)$. The statistical analysis results indicated that the $\mathrm{Pb}$ concentrations in all experimental $F$. limnocharis muscle samples were significantly different from the controls $(\mathrm{p}<0.05)$.

These results suggest that the $\mathrm{Pb}$ found in the water samples originated from $F$. limnocharis frogs. It appeared that higher concentrations of injected $\mathrm{Pb}$ and longer exposure times resulted in increased $\mathrm{Pb}$ concentrations in the water. $\mathrm{Pb}$ accumulates mainly in the liver and kidney of $F$. limnocharis (Hopkins 1989, Jan ová et al. 2002, Zhang et al. 2007) and is excreted through the urine, faeces and skin (Akerstrom et al. 2013). Consequently, F. limnocharis may not eliminate all of the $\mathrm{Pb}$ from their bodies, and some $\mathrm{Pb}$ remains in the muscles and other organs.

Several studies are confirming that the $\mathrm{Pb}$ concentrations absorbed in frog bodies can be transported to various target organs, such as the liver and kidney, compared with transportation to the muscles (Jarup et al. 1988, Grosicki \& Kowalski 2002, Formicki \& Stawarz 2004). The intracellular movement of $\mathrm{Pb}$ across cellular membranes occurs via active transport, which is facilitated by P-type ATPase ionic pumps (Zelikoff et al. 1988, Gatti et al. 2000, Patric 2006). Among heavy metals, $\mathrm{Pb}$ has a higher propensity to bioaccumulate in frog organs involved in the detoxification process.

Genotoxic effects in $\boldsymbol{F}$. limnocharis: Fourteen clear and reproducible ISSR primers generated ISSR bands for the 24, 48 and 72 hours groups as 1158, 1205 and 1277, respectively, ranging in size from $100 \mathrm{bp}$ to $3000 \mathrm{bp}$. Examples of these ISSR bands for different primers are shown in Fig. 1. These bands were used for dendrogram construction for each duration of exposure (Figs. 2-4). For each dendrogram, the closest individuals from the same $\mathrm{Pb}$ concentration clusters demonstrate that they are genetically similar. These clusters were grouped at varying distances between the other $\mathrm{Pb}$ concentration groups with a trend towards greater distances as greater $\mathrm{Pb}$ concentrations.

The genetic differentiation values between individuals of each $\mathrm{Pb}$ concentration and duration of exposure groups were almost identical (0.98-1.00). The minimum and maximum ranges of genetic differentiation values were $0.51-0.96,0.44-$ 0.81 and $0.49-0.74$ for the 24,48 and 72 hours of exposure dendrograms, respectively. At 24 hours of exposure, the differentiation values of the experimental groups compared to the control group were $0.54-0.55,0.51-0.52$ and $0.53-0.54$ for 5,10 and $20 \mathrm{mg} . \mathrm{L}^{-1}$, respectively. At 48 hours of exposure, the 
Table 2: The $\mathrm{Pb}$ acetate concentrations in water samples $(\bar{X} \pm \mathrm{SD})$.

\begin{tabular}{|c|c|c|c|c|}
\hline \multirow[t]{2}{*}{ Lead acetate concentration $\left(\mathrm{mg} \cdot \mathrm{L}^{-1}\right)$} & \multicolumn{3}{|c|}{$\mathrm{Pb}$ concentration in the water $\left(\mathrm{mg} . \mathrm{L}^{-1}\right)$} & \multirow[t]{2}{*}{ Thailand standard* $\left(\mathrm{mg} . \mathrm{L}^{-1}\right)$} \\
\hline & $24 \mathrm{~h}$ & $48 \mathrm{~h}$ & $72 \mathrm{~h}$ & \\
\hline 0 & ND & ND & $\mathrm{ND}$ & 0.05 \\
\hline 5 & $0.01 \pm 0.00^{\mathrm{a}}$ & $0.01 \pm 0.00^{\mathrm{a}}$ & $0.03 \pm 0.00^{\mathrm{b}}$ & \\
\hline 10 & $0.02 \pm 0.00^{\mathrm{a}}$ & $0.03 \pm 0.00^{b}$ & $0.03 \pm 0.01^{b}$ & \\
\hline 20 & $0.03 \pm 0.01^{b}$ & $0.03 \pm 80.01^{b}$ & $0.05 \pm 0.01^{b}$ & \\
\hline
\end{tabular}

Remarks: ND=Not detected (less than the detection limit of $\mathrm{Pb}$ ); $\mathrm{a}=$ nonsignificant difference compared to the control; $b=$ significant difference compared to the control (p 0.05).

*Water quality standards for surface water sources, Pollution Control Department, Ministry of Natural Resources and Environment, Thailand (PCD 2014).

Table 3: The $\mathrm{Pb}$ concentrations in F. limnocharis muscles $(\bar{X} \pm \mathrm{SD})$.

\begin{tabular}{|c|c|c|c|c|}
\hline \multirow[t]{2}{*}{ Lead acetate concentration $\left(\mathrm{mg} \cdot \mathrm{kg}^{-1}\right)$} & \multicolumn{3}{|c|}{$\mathrm{Pb}$ concentration in $F$. limnocharis muscles $\left(\mathrm{mg} \cdot \mathrm{kg}^{-1}\right)$} & \multirow[t]{2}{*}{ Thailand standard* $\left(\mathrm{mg} \cdot \mathrm{kg}^{-1}\right)$} \\
\hline & 24 hours & 48 hours & 72 hours & \\
\hline 0 & ND & ND & ND & \multirow{4}{*}{$\leq 0.03$} \\
\hline 5 & $0.28 \pm 0.03^{\mathrm{a}}$ & $0.44 \pm 0.02^{\mathrm{a}}$ & $0.32 \pm 0.06^{\mathrm{b}}$ & \\
\hline 10 & $0.27 \pm 0.09^{\mathrm{a}}$ & $0.34 \pm 0.03^{b}$ & $0.30 \pm 0.02^{b}$ & \\
\hline 20 & $0.35 \pm 0.03^{b}$ & $0.63 \pm 0.04^{b}$ & $0.78 \pm 0.04^{\mathrm{b}}$ & \\
\hline
\end{tabular}

Remarks: ND=Not detected (less than the detection limit of $\mathrm{Pb}$ ); $\mathrm{a}=$ nonsignificant compared to the control; $\mathrm{b}=$ significant compared to the control (p 0.05).

*Standard for contaminants in the food according to the Notification of the Ministry of Public Health No. 273/2 (Ministry of Public Health 2003).

differentiation values of the experimental groups compared group compared to the control group were 0.69, 0.59-0.60 with the controls were $0.55,0.44-0.45$ and 0.48 for 5,10 and 0.49 for 5,10 and $20 \mathrm{mg} . \mathrm{L}^{-1}$, respectively. As $\mathrm{Pb}$ was and $20 \mathrm{mg} . \mathrm{L}^{-1}$, respectively. At 72 hours of exposure, the detected in all F. limnocharis samples except for the control differentiation values of the samples from each experimental group, this suggests that the injected $\mathrm{Pb}$ was responsible

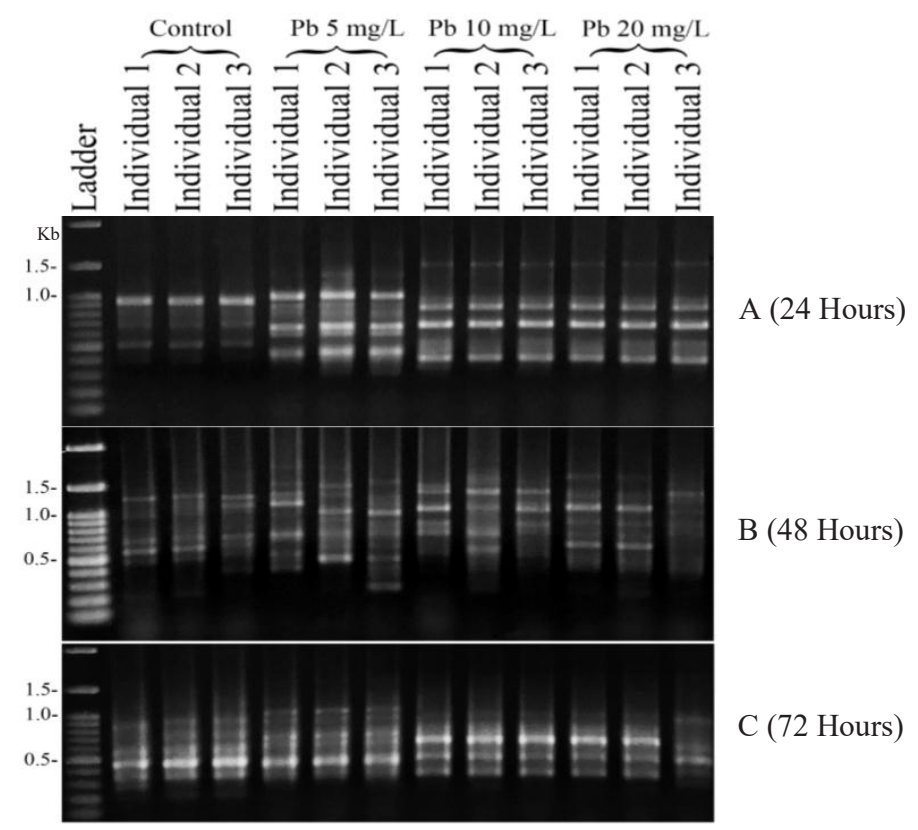

Fig. 1: Examples of the ISSR fingerprints from F. Limnocharis samples in the three experimental groups and the control groups for durations of 24,48 and 72 hours generated using the primers ACACACACACACACACG (A), CACACACACACAGG (B) and CACCACCACGC (C). 


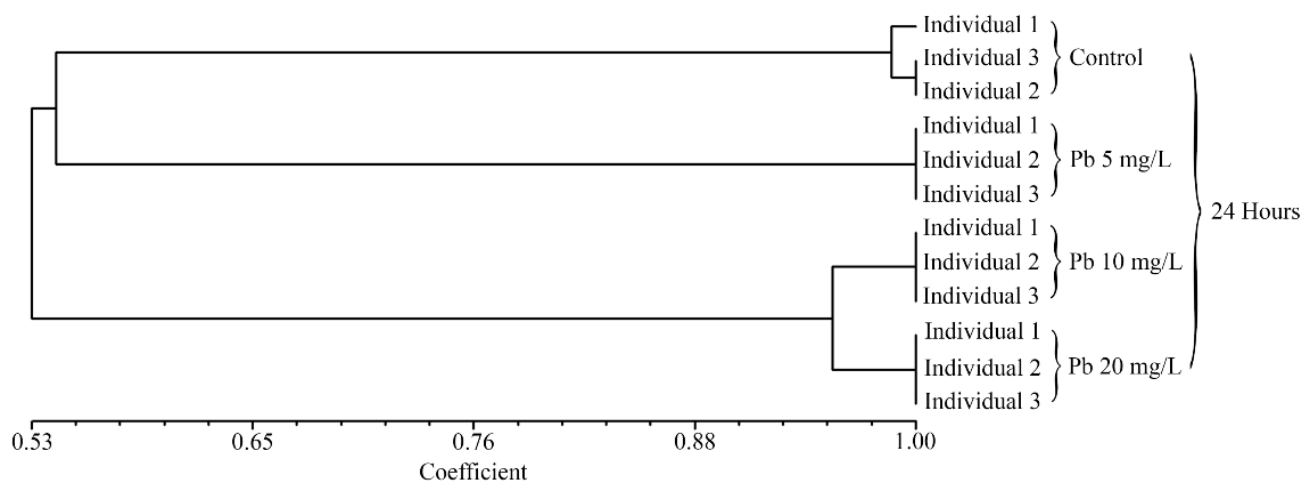

Fig. 2: The dendrogram constructed using 13 ISSR primers and the NTSYSpc 2.10p program showing the genetic relationships among the individual samples in the three experimental groups and the control group for 24 hours.

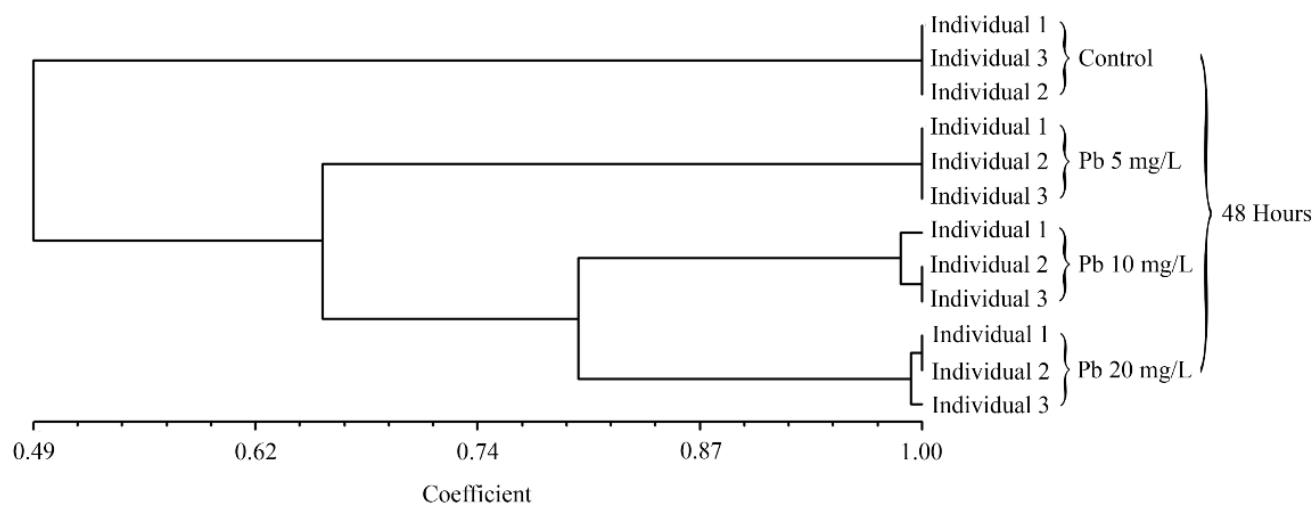

Fig. 3: The dendrogram constructed using 12 ISSR primers and the NTSYSpc 2.10p program showing the genetic relationships among the individual samples in the three experimental groups and the control group for 48 hours.

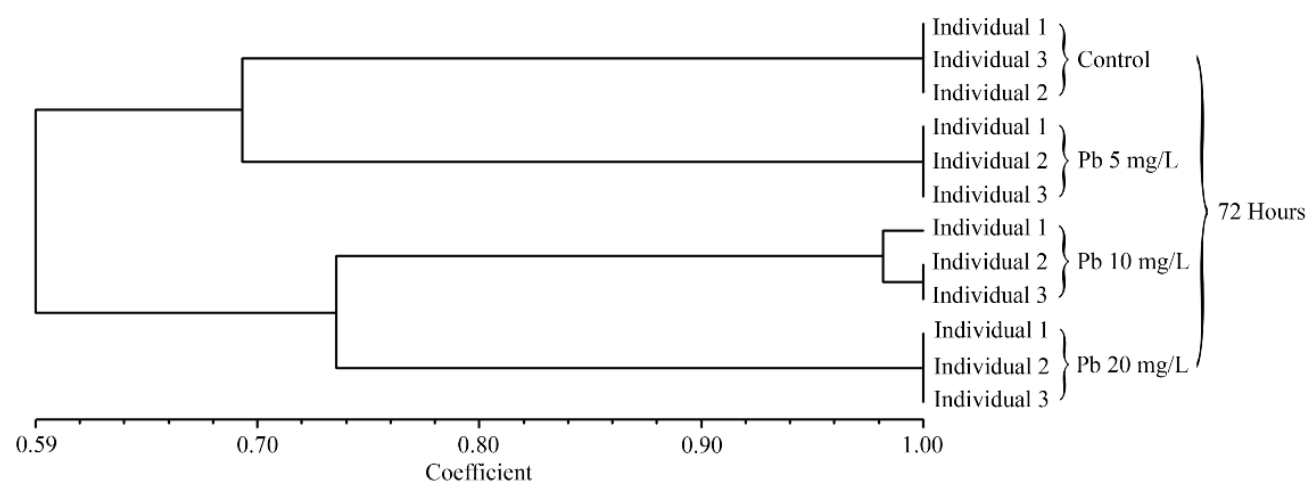

Fig. 4: The dendrogram constructed using 14 ISSR primers and the NTSYSpc 2.10p program showing the genetic relationships among the individual samples in the three experimental groups and the control group for 72 hours.

for the genotoxic effects, as evidenced by the genetic differentiation values of the experimental groups compared with the control group. Differences in $\mathrm{Pb}$ concentrations were calculated between the groups and correlated against the genetic differentiation values with linear regression analysis. There was no significant correlation between the concentration differences and genetic differentiation values for 24 hours $\left(R^{2}=0.05, p=0.89\right)$ (Fig. 5) and 48 hours $\left(R^{2}\right.$ $=0.086, p=0.57$ ) of exposure (Fig. 6). For 72 hours of exposure, there was a significant correlation between the differences in $\mathrm{Pb}$ concentration and genetic similarity values $\left(R^{2}=0.77, p<0.05\right)($ Fig. 7). These results suggest that the 
genotoxic effects of $\mathrm{Pb}$ depend on both the exposure time and concentration.

The results of this study indicate that intraperitoneal injection of $\mathrm{Pb}$ solutions leads to contamination of the water in the frog's environment by excretion via urine and faeces. This study also showed that $\mathrm{Pb}$ induced genotoxicity in a time and concentration-dependent manner. These results have also been observed in many other studies; however, the vast majority of previous studies relating to the genotoxic effects of $\mathrm{Pb}$ have been undertaken in fish, rats, mice and rabbits, with a clear gap in the literature regarding frogs (García-Lestón et al. 2010). There are various mechanisms of genotoxicity that have been discussed in previous literature, including oxidative stress from the generation of reactive oxygen species and by DNA repair enzymes (Hwang \& Kim 2007, Gueranger et al. 2011, Krisko \& Radman 2013, McAdam et al. 2016). The reported mechanisms may be responsible for the genotoxic effects of $\mathrm{Pb}$ observed in the frogs in this study.

Frogs were selected for this study because they have the potential to be useful biomarkers for environmental contamination of $\mathrm{Pb}$ due to their highly permeable skin (Othman 2009; Thammachot et al. 2012). The disadvantage of this study in exploring the application of frogs as biomarkers of the genotoxic effects of the environment is that in vivo intraperitoneal injections do not completely simulate exposure to $\mathrm{Pb}$ in the natural environment. Therefore, this study provides basic knowledge for future research, particularly for the use of frogs as biomarkers of heavy metal contamination in relation to genotoxicity consequences.

\section{CONCLUSION}

Intraperitoneal injection of a $\mathrm{Pb}$ solution into $F$. limnocharis frogs was responsible for the contamination of lead into water and its accumulation in muscles. Genotoxicity effects after $\mathrm{Pb}$ exposure, as evidenced by dendrograms and genetic differentiation values, are concentration-dependent and additive. This study revealed that $F$. limnocharis frogs can potentially be used as biomarkers for $\mathrm{Pb}$ contamination through measurement of the genotoxic effects.

\section{ACKNOWLEDGMENTS}

This research was supported by the Research Group on Toxic Substances in Livestock and Aquatic Animals and the Gradn uate School of Khon Kaen University, Thailand.

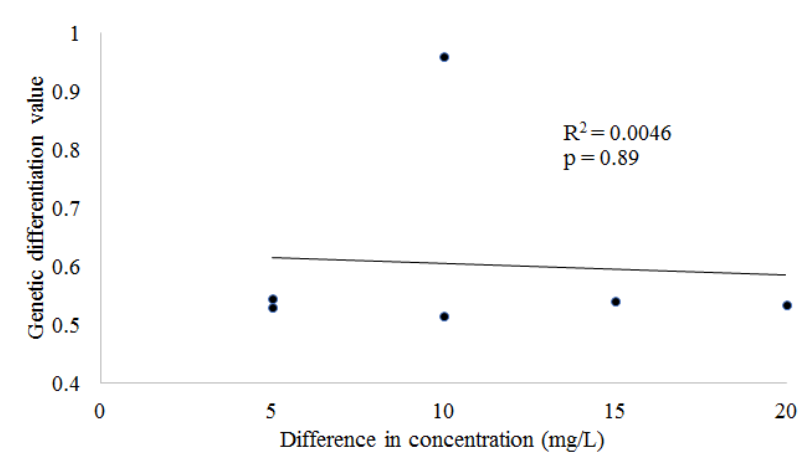

Fig. 5: Genetic differentiation values according to differences in the concentration for 24 hours of exposure.

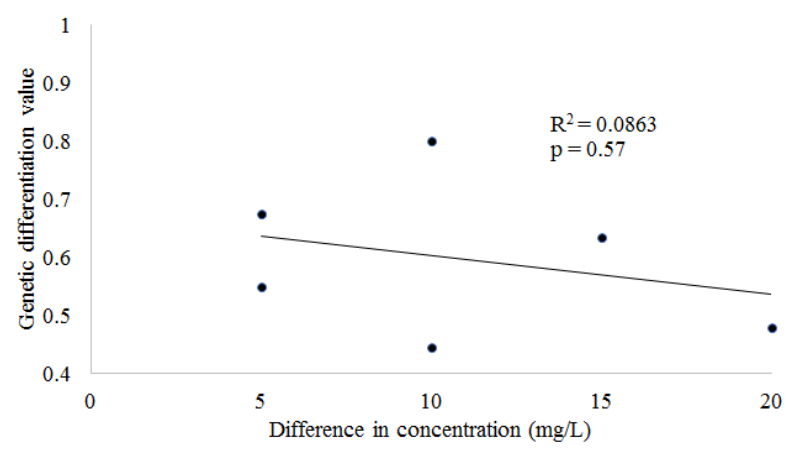

Fig. 6: Genetic differentiation values according to differences in the concentration for 48 hours of exposure.

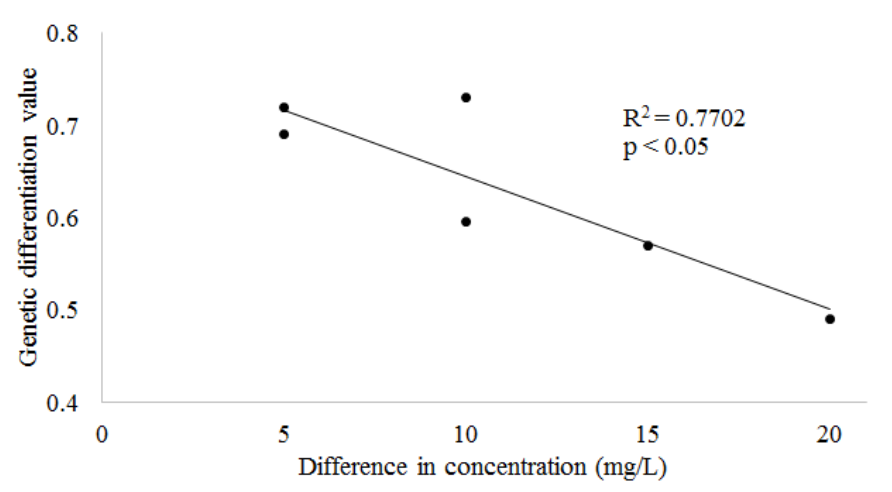

Fig. 7: Genetic differentiation values according to differences in the concentration for 72 hours of exposure. 


\section{REFERENCES}

Agency for Toxic Substances and Disease Registry (ATSDR) 2007. Toxicological Profile for Lead. Agency for Toxic Substances and Disease Registry, Washington DC, USA.

Akerstrom, M., Barregard, L., Lundh, T. and Sallsten, G. 2013. The relationship between cadmium in kidney and cadmium in urine and blood in an environmentally exposed population. Toxicol. Appl. Pharmacol., 268(3): 286-93.

Al-Qurainy, F., Khan, S., Tarroum, M., Nadeem, M., Alansi, S. and Alshameri, A. 2017. Biochemical and genetical responses of Phoenix dactylifera L. to cadmium stress. Biomed. Res. Int., 4: 1-9.

American Public Health Association (APHA) 2005. Standard Methods for the Examination of Water and Wastewater. American Public Health Association, $21^{\text {st }}$ edition. Washington DC, USA.

Behura, S.K. 2006. Molecular marker systems in insects: current trends and future avenues. Mol. Ecol., 15(11): 3087-3113.

Beyersmann, D. and Hartwig, A. 2008. Carcinogenic metal compounds: Recent insight into molecular and cellular mechanisms. Arch. Toxicol., 82: 493-512.

Burlibasa, L. and Gavrila, L. 2011. Amphibians as model organisms for study environmental genotoxicity. Appl. Ecol. Env. Res., 9(1): 1-15.

Chand, V. and Prasad, S. 2013. ICP-OES assessment of heavy metal contamination in tropical marine sediments: A comparative study of two digestion techniques. Microchemical, 111: 53-56.

Cleveland, L.M., Minter, M.L., Cobb, K.A., Scott, A.A. and German, V.F. 2008. Lead hazards for pregnant women and children: Part 1: immigrants and the poor shoulder most of the burden of lead exposure in this country. Part 1 of a two-part article details how exposure happens, whom it affects, and the harm it can do. Nursing American Nurses Association, 108: 40-49.

Correia, P.R.M., Oliveira, E. and Oliveira, P.V. 2000. Simultaneous determination of $\mathrm{Cd}$ and $\mathrm{Pb}$ in foodstuffs by electro-thermal atomic absorption spectrometry. Anal. Chim. Acta., 405(1-2): 205-211.

Falfushinska, H., Loumbourdis, N., Romanchuk, L. and Stolyar, O. 2008. Validation of oxidative stress responses in two populations of frogs from Western Ukraine. Chemosphere, 73(7): 1096-1101.

Formicki, G. and Stawarz, R. 2004. Cadmium accumulation and depuration in common frog (Rana temporaria L.) larvae exposed to ultraviolet radiation. Risk Factors of Food Chain, Slovak University of Agriculture, Slovakia.

Garcia-Leston, J., Méndez, J., Pásaro, E. and Laffon, B. 2010. Genotoxic effects of lead: An updated review. Environ. Int., 36: 623-636.

Gatti, D., Mitra, B. and Rosen, B.P. 2000. Escherichia coli soft metal iontranslocating ATPases. J. Biol. Chem., 275(44): 34009-34012.

Grosicki, A. and Kowalski, B. 2002. Whole-body and organ retention of cadmium after repeated administration to rats. Bull. Vet. Inst. Pulawy., 46: 143-147.

Gueranger, Q., Kia, A., Frith, D. and Karran, P. 2011. Crosslinking of DNA repair and replication proteins to DNA in cells treated with 6-thioguanine and UVA. Nucleic. Acids. Res., 39: 5057-5066.

Héry, M., Gault, A.G., Rowland, H.A., Lear, G., Polya, D.A. and Lloyd, J.R. 2008. Molecular and cultivation dependent analysis of metal-reducing bacteria implicated in arsenic mobilization in south-east Asian aquifers. Appl. Geochem., 23: 3215-3223.

Hopkins, S.P. 1989. Ecophysiology of Metals in Terrestrial Invertebrates, Barking (UK), Elsevier Applied Science.

Huang, Y. and Li, L. 2013. DNA crosslinking damage and cancer a tale of friend and foe. Transl. Cancer. Res., 2(3): 144-54.

Hwang, E.S. and Kim, G.H. 2007. Biomarkers for oxidative stress status of DNA, lipids, and proteins in vitro and in vivo cancer research. Toxicology, 229: 1-10.

Internatoinal Agency for the Research on Cancer (IARC) 2004. Inorganic and Organic Lead Compounds. IARC Monographs on the Evaluation of Carcinogenic Risks to Human. Lyon.

Jaishankar, M., Mathew, B.B., Shah, M.S. and Gowda, K.R.S. 2014. Biosorption of few heavy metal ions using agricultural wastes. J. Environ. Poll. Hum. Health, 2(1): 1-6.

Jan ová, A., Massányi, P. and Gálová, J. 2002. The concentration of cadmium and lead in liver and kidneys in Apodemus flavicollis and Cleithrionomys glareolus. NIH, 46: 65-67.

Jarup, L., Berglund, M., Elinder, C.G., Nordberg, G. and Vahter, M. 1988. Health effects of cadmium exposure - A review of the literature and a risk estimate. Scand. J. Work. Environ. Health, 24(1): 1-51.

Kakker, P. and Jaffery, F.N. 2004. Biological markers for metals toxicity. Environ. Toxicol. Pharmacol., 19: 335-49.

Kalia, K. and Flora, S.J. 2005. Strategies for safe and effective therapeutic measures for chronic arsenic and lead poisoning. J. Occup. Health, 47: 1-21.

Kasuba, V., Rozgaj, R., Fuic, A., Varnai, V.M. and Piasek, M. 2004. Lead acetate genotoxicity in suckling rats. Biologia., 59(6): 779-785.

Kerby, J.L., Richards, K.L., Storfer, A. and Skelly, D.K. 2010. An examination of amphibian sensitivity to environmental contaminants: Are amphibians poor canaries? Ecol. Lett., 13: 60-67.

Kosnett, M.J. 2006. Lead. In: Olson K.R, Editor. Poisoning and Drug Overdose. $5^{\text {th }}$ ed., McGraw Hill Professional.

Krisko, A. and Radman, M. 2013. Phenotypic and genetic consequences of protein damage. Plos. Genet., 9: e1003801.

Linder, G. and Grillitsch, B. 2000. Ecotoxicology of metals. In: Sparling DW, Linder G, Bishop CA, Editors. Ecotoxicology of Amphibians and Reptiles. Pensacola, FL. Society of Environmental Toxicology and Chemistry (SETAC).

Liu, W.Y., Wang, C.Y., Wang, T.S., Fellers, M.G., Lai, B.C. and Kam, Y.C. 2011. Impacts of the herbicide butachlor on the larvae of a paddy field breeding frog (Fejervarya limnocharis) in subtropical Taiwan. Ecotoxicology, 20(2): 377-384.

Mahfouz, H. and Rayan, W.A. 2016. Assessment of lead stress using genome template stability in Hordeum vulgare. Egypt. J. Genet. Cytol., 45: 297-321.

Martin, S. and Griswold, W. 2009. Human health effects of heavy metals. Environ. Sci. Technol. Briefs Citizens, 15: 1-6.

McAdam, E., Brem, R. and Karran, P. 2016. Oxidative stress-induced protein damage inhibits DNA repair and determines mutation risk and anticancer drug effectiveness. Mol. Cancer. Res., 14: 612-622.

Méndez-Gómez, J., García-Vargas, G.G., López-Carrillo, L., CalderónAranda, E.S., Gómez, A., Vera, E., Valverde, M., Cebrián, M.E. and Rojas, E. 2008. Genotoxic effects of environmental exposure to arsenic and lead on children in region Lagunera, Mexico. Ann. NY. Acad. Sci., 1140: 358-367.

Ministry of Public Health. 2003. Standard of Contaminants in Food. Notification of the Ministry of Public Health No. 273/2, Bangkok, Thailand.

Mitchell, E., Frisbie, S. and Sarkar, B. 2011. Exposure to multiple metals from groundwater a global crisis: geology, climate change, health effects, testing, and mitigation. Metallomics, 3: 874-908.

Navas, A.A., Guallar, E., Silbergeld, E.K. and Rothenberg, S.J. 2007. Lead exposure and cardiovascular disease a systematic review. Environ. Health. Perspect., 115(3): 472-82.

Needleman, H. 2004. Lead poisoning. Annu. Rev. Med., 55: 209-222.

Neeratanaphan, L., Sudmoon, R. and Chaveerach, A. 2014. Assessment of genotoxicity through ISSR marker in Pistia stratiotes induced by lead. Environment Asia, 7(2): 99-107.

Olafisoye, B.O., Adefisoye, T. and Osibote, O.A. 2013. Heavy metals contamination of water, soil, and plants around an electronic waste dumpsite. Pol. J. Environ. Stud., 22(5): 1431-1439.

Othman, M.S. 2009. Using the Rice Frog (Fejervarya limnocharis) as Asentinel Species for Cadmium Contamination in Tak Province, Thailand. Doctoral dissertation, Program in Environmental 
Management, Graduate School, Chulalongkorn University, Thailand.

Patra, R.C., Swarup, D. and Dwidedi, S.K. 2001. Antioxidant effects of $\alpha$ tocopherol, ascorbic acid and L-methionine on lead-induced oxidative stress of the liver, kidney and brain in rats. Toxicology, 162: 81-88.

Patric, L. 2006. Lead toxicity part II: the role of free radical damage and the use of antioxidants in pathology and treatment of lead toxicity. Altern. Med. Rev., 11(2): 114-127.

Pollution Control Department (PCD) 2014. Thailand State of Pollution Report. Ministry of Natural Resources, Bangkok, Thailand.

Rohlf, F.J. 2009. NTSYS_pc: Numerical Taxonomy and Multivariate Analysis System, Version 2.2. Applied Biostatistics Inc., New York.

Sharma, S., Sharma, V., Paliwal, R. and Pracheta. 2011. Lead toxicity, oxidative damage and health implications, a review. Int. J. Biotechnol. Mol. Biol. Res., 2(13): 215-221.

Thailand Pollution Control Department (TPCD) 1986. The Standard Levels of Heavy Metals in Tissues of Aquatic Animals. Notification in Ministry of Public Health, No. 98. Bangkok, Thailand.

Thailand Pollution Control Department (TPCD) 2001. Water Quality Standards. Notification in Ministry of Public Health, No. 98, Bangkok, Thailand.

Thammachoti, P., Khonsue, W., Kitana, J., Varanusupakul, P. and Kitana, N. 2012. Morphometric and gravimetric parameters of the rice frog
Fejervarya limnocharis living in areas with different agricultural activity. Environ. Prot., 3: 1403-1408.

Vargas, I., Castillo, C. and Posadas, F. 2003. Acute lead exposure induces renal heme oxygenase- 1 and decreases urinary $\mathrm{Na}^{+}$excretion. Hum. Exp. Toxicol., 22: 237-244.

Wu, K., Jones, R., Dannaeberger, L. and Scolnik, P.A. 1994. Detection of microsatellite polymorphisms without cloning. Nucleic. Acids. Res., 22: 3257-3258.

Yan, X., Liu, M., Zhong, I., Guo, J. and Wu, W. 2018. How human activities affect heavy metal contamination of soil and sediment in a long-term reclaimed area of the Liaohe river delta, North China. Sustainability, 10: 338 .

Zelikoff, J.T., Li, J.H., Hartwig, A., Wang, X.W., Costa, M. and Rossman, T.G. 1988. Genetic toxicology of lead compounds. Journal of Carcinogenesis, 9: 1727-1732.

Zhang, Y., Huang, D., Zhao, D., Long, J., Song, G. and Li, A. 2007. Longterm toxicity effects of cadmium and lead on Bufo raddei tadpoles. Bull. Environ. Contam. Toxicol., 79(4): 178-183.

Zietkiewicz, E., Rafalski, A. and Labuda, D. 1994. Genome fingerprinting by simple sequence repeat (SSR) anchored polymerase chain reaction amplification. Genomics, 20: 176-183. 